\title{
Should I Perform an Electroencephalography in Patients with Syncope?
}

\section{Senkoplu Hastalarda Elektroensefalografi Yapmalı Mıyım?}

\author{
(D) Mehlika Panpallı Ateş, (D) Fatma Yılmaz Can
}

University of Health Sciences Turkey, Dışkapı Yıldırım Beyazıt Training and Research Hospital, Clinic of Neurology, Ankara, Turkey

\section{Abstract}

Objective: Temporary loss of consciousness that occurs with temporary global cerebral hypoperfusion is defined as syncope. Infrequent changes can be seen in electroencephalography (EEG) during syncope. These EEG changes and findings are in the form of symmetric slowed-waves, spikes, or spike-wave complexes. In this study, the results and necessity of EEG in patients who applied to the neurology outpatient clinic with the complaint of syncope were evaluated.

Method: In this study, the EEG results of 261 patients aged 17-86 years, who were evaluated in the general neurology outpatient clinic with the diagnosis of syncope between September 2018 and March 2019, were retrospectively analyzed. Patients with epilepsy were excluded. Data were obtained considering the demographic characteristics of the patients, comorbidities, the absence of epilepsy diagnosis, and the drugs they used.

Results: Of the 261 syncope patients, $77 \%(n=201)$ had normal EEG findings, while $16.5 \%(n=43)$ had symmetric slowed-waves and sharplycontoured waves, $1.5 \%(n=4)$ had sharp and sharply-contoured waves, $1.5 \%(n=4)$ had focal slowed-waves, and $3.4 \%(n=9)$ had spike, and spike-wave complexes.

Conclusion: In the diagnosis of patients presenting with syncope, taking a detailed history and questioning the background, first cardiovascular examination are more instructive than EEG. EEG should be performed in patients who cannot be decided with their clinic. Despite this, if it is still not sure, the diagnosis of epilepsy should be postponed and patients should be called for frequent control.

Keywords: Electroencephalography, epilepsy, seizure, syncope

\section{Öz}

Amaç: Geçici global serebral hipoperfüzyon ile ortaya çıkan geçici bilinç kaybı senkop olarak tanımlanmaktadır. Senkop esnasında elektroensefalografide (EEG) sık olmayan değişiklikler görülebilir. Bu EEG değişiklikleri ve bulguları simetrik yavaşlama, diken ya da dikendalga kompleksleri şeklindedir. Bu çalışmada, senkop şikayetiyle nöroloji polikliniğine başvuran hastalarda yapılan EEG sonuçları ve gerekliliğ değerlendirildi.

Yöntem: Bu çalışmada, Eylül 2018-Mart 2019 arasında senkop tanıs ile genel nöroloji polikliniğinde değerlendirilen 17-86 yaş aralığında 261 hastanın, EEG sonuçları retrospektif olarak incelendi. Hastaların demografik özellikleri, ek hastalıkları, epilepsi tanısının olmaması ve kullandıkları ilaçlar dikkate alınarak veriler elde edildi.

Bulgular: Hastaların \%77'sinin ( $n=201)$ EEG'si normaldi. Hastaların $\% 16,5^{\prime}$ inde $(n=43)$ simetrik yavaşlama ve keskin karakterli dalgalar $\% 1,5^{\prime}$ inde $(n=4)$ keskin ve keskin karakterli dalgalar, \%1,5'inde (4) fokal yavaşlık ve \%3,4'ünde (9) diken, diken-dalga kompleksleri izlendi.

Sonuç: Senkop ile başvuran hastalarda teşhiste, ayrıntılı öykü alınması ve özgeçmiş sorgulanması, öncelikle kardiyovasküler inceleme yapılması, EEG'den daha yol göstericidir. Kliniği ile karar verilemeyen, arada kalınan hastalarda EEG yapılmalıdır. Buna rağmen yine de emin olunmazsa epilepsi tanısı ertelenmeli, hastalar sık kontrole çağrılmalıdır.

Anahtar kelimeler: Elektroensefalografi, epilepsi, nöbet, senkop 


\section{Introduction}

The loss of consciousness is a frequent cause of emergency room visits in the general neurology practice. It is important to determine whether it is associated with an underlying neurological disorder.

Syncope is a temporary loss of consciousness because of general cerebral hypoperfusion that is characterized by rapid onset, short course, and spontaneous full recovery $(1,2)$. Syncope can be categorized into three main groups as reflex (neurally mediated), orthostatic, and cardiovascular syncope. Reflex syncope is generally subdivided into two types (i.e. sympathetic and parasympathetic) based on the efferent pathways involved; vasovagal syncope is also a type of reflex syncope (3).

Vasovagal syncope is associated with reduced cardiac output resulting from bradycardia and reduced vasoconstriction due to the activation of the autonomous nervous system (4). Signs and symptoms of syncope may present in two distinct categories. The first category involves those that are related to the cause of syncope, such as palpitations as in arrhythmia and paleness in reflex symptom. On the other hand, the second category is related with the results of cerebral and retinal hypoperfusion, and involves visual disturbance, blurred consciousness, and motor effects such as the loss of voluntary motor control, myoclonic jerks, as well as stiffness $(4,5)$.

Of all syncope events, $12 \%$ are accompanied by seizure-like symptoms due to the global cerebral hypoperfusion (6). Again, inter-ictal changes of electroencephalography (EEG) have been reported in up to $30 \%$ of these patients (7).

In this study, patients diagnosed with syncope by virtue of anamnesis, physical examination, and electrophysiological and cardiological investigations were evaluated.

\section{Materials and Methods}

Results of neurological examination, EEG, cranial magnetic resonance imaging (MRI), cardiologic examination, and systemic diseases were retrospectively evaluated among patients aged between 17 and 85 years, presenting to our neurology outpatient unit between September 2018 and March 2019. In hospital, patients who are at the age of 17 years and older are examined in adult neurology department. Patients who are children under the age of 16 years are evaluated by pediatric neurology department.

Inclusion criteria were for patients who had not previously been diagnosed and treated for syncope. Patients with diabetes mellitus characterized by recurrent episodes of hypoglycemia/hyperglycemia, known cardiac conduction disorders, epilepsy, history of cerebrovascular disorder, and intracranial mass lesion disorders were excluded.

Demographic characteristics of patients were recorded. Also, medication history, particularly drugs that could affect the orthostatic tolerance, was recorded.

\section{Statistical Analyses}

Statistical analysis was carried out using a SPSS ${ }^{\circledR}$ (Statistical Package for Social Sciences) 22.0 for Windows and Mac os x. Categorical variables were expressed as frequency distribution, and continuous variables as descriptive statistics [mean \pm standard deviation (SD)]. The difference between the two independent groups for variables with normal distribution was tested using the Independent Sample t-test, while the Mann-Whitney U test was used for variables without normal distribution. The association between two independent categorical variables was evaluated with the chi-square test. Categorical variables were expressed as $\mathrm{N}(\%)$, while variables with normal distribution were expressed as mean $( \pm \mathrm{SD})$ and variables without normal distribution were expressed as median (minimum-maximum). A p-value less than 0.05 was considered statistically significant.

\section{Results}

Two hundred sixty one syncope patients (median age: 38 years, range 17-86 years) were assessed between September 2018 and March 2019. Of the participants, $47.5 \%(n=124)$ were female and $52.5 \%(n=137)$ were male. The male and female patients were comparable in terms of median age [39 (18-86), 37.7 (17-84)] ( $\mathrm{p}=0.482)$. There was no gender difference between those with EEG pathology $(\mathrm{p}=0.884)$ (Table 1).

There were no drugs affecting orthostatic tolerance such as tricyclic antidepressant, monoamine oxidase inhibitor, antipsychotic, diuretic, $\alpha$-adrenergic receptor blocker.

Table 1. Demographic characteristics of syncope patients

\begin{tabular}{|c|c|c|}
\hline \multicolumn{2}{|l|}{$\begin{array}{l}\text { Gender } \\
(261, \%)\end{array}$} & \multirow[t]{2}{*}{$\mathbf{p}$} \\
\hline $\begin{array}{l}\text { Female } \\
124(47.5 \%)\end{array}$ & $\begin{array}{l}\text { Male } \\
137(52.5 \%)\end{array}$ & \\
\hline $37.5(17-84)$ & $39(18-86)$ & 0.482 \\
\hline 29 (48.3\%) & 31 (51.7\%) & 0.884 \\
\hline
\end{tabular}

EEG: Electroencephalography 
Only, drugs containing $\alpha$-adrenergic receptor blocker or diuretic were used for a long time in 14 patients. EEG results of patients using these drugs were normal.

One of our female patients had maternal history of seizures / pseudo-seizures. Her EEG result was normal.

Of all the patients, an EEG normality was detected in $77 \%$ $(\mathrm{n}=201)$. Among these 261 patients, sleep-deprived EEG was performed in $19.1 \%$ (50) patients with suspected EEG abnormality and clinically undetermined status, and the results of $18 \%(n=47)$ were normal and only $1.1 \%(n=3)$ were pathological findings.

In EEG, $16.5 \%$ ( $n=43$ ) of the patients had symmetric slowedwaves and sharply-contoured waves, $1.5 \% \quad(n=4)$ had sharp and sharply-contoured waves, $1.5 \%(\mathrm{n}=4)$ had focal slowed-waves, and $3.4 \%(\mathrm{n}=9)$ had spike, and spike-wave complexes (Table 2).

Doppler ultrasonography was performed in $13.4 \%(n=27)$ of the patients with normal EEG, and that showed occlusion (left internal carotid artery) in 1 patient, stenosis in 2 patients (1 of them, started treatment because of significant ischemic risk associated with $>50 \%$ contraction), plaque in 7 patients ( 1 of them was started treatment because of ulcerated soft plaque) (Table 3 ).
A cranial MRI was performed to rule out possible cerebrovascular disorders, intracranial mass lesions, and other disorders. Cranial MRI in patients with EEG abnormalities showed no intracranial pathology that could be associated with syncope. But interesting point is that EEG abnormality was found in patients with significant MRI pathology. However, besides that, MRI of $68.3 \%(n=41)$ of syncope patients with EEG abnormality was normal (Table 4).

At the same time, patients with normal EEG were referred to cardiology unit considering cardiogenic syncope. Blood pressure Holter and echocardiography was performed in $24.4 \%(n=49)$ of the patients. Cardiac pathology was found in $11(5.5 \%)$ patients.

In summary, among all patients, EEG normality was found in $77 \%(n=201)$, and results were pathological in $23 \%(n=60)$ of patients.

When EEG results were classified as (1) normal, (2) slow waves, and (3) epileptiform discharges (spike/sharp waves), among all the EEG reports, $77 \%(\mathrm{n}=201)$ were normal, $16.5 \%$ $(n=43)$ of them were slow waves, and $6.5 \%(n=17)$ of them were found epileptiform discharges (spike/sharp waves).

Table 2. EEG results in patients with syncope

\begin{tabular}{llllll} 
& EEG & & & \\
\hline Syncope & Normal & $\begin{array}{l}\text { Symmetric slowed-waves and } \\
\text { sharply-contoured waves }\end{array}$ & $\begin{array}{l}\text { Sharp and sharply- } \\
\text { contoured waves }\end{array}$ & $\begin{array}{l}\text { Focal slowed- } \\
\text { waves }\end{array}$ & $\begin{array}{l}\text { Spike, spike- } \\
\text { wave complex }\end{array}$ \\
\hline $\mathbf{n = 2 6 1 ( 1 0 0 \% )}$ & $201(77 \%)$ & $43(16.5 \%)$ & $4(1.5 \%)$ & $4(1.5 \%)$ & $9(3.4 \%)$ \\
\hline
\end{tabular}

EEG: Electroencephalography

Table 3. Carotid artery/vertebral artery Doppler US results in 36 syncope patients

\begin{tabular}{lllll} 
& Normal & Plaque & Stenosis & Occlusion \\
\hline $\mathbf{n = 3 6 ( 2 3 . 8 \% )}$ & $23(8.8 \%)$ & $9(3.4 \%)$ & $3(1.1 \%)$ & $1(0.4 \%)$ \\
\hline
\end{tabular}

US: Ultrasound

Table 4. Cranial MRI results with EEG in syncope patients

\begin{tabular}{lll} 
& EEG & \\
\hline Cranial MRI & Normal & Abnormal \\
\hline Normal & $160(79.6 \%)$ & $41(20.4 \%)$ \\
Non-specific ischemic-gliotic foci & $26(78.8 \%)$ & $7(21.2 \%)$ \\
Ischemic encephalomalastic area & $12(60 \%)$ & $8(40 \%)$ \\
Arachnoid cyst & $2(66.7 \%)$ & $1(33.3 \%)$ \\
Megasisterna magna & $1(50 \%)$ & $1(50 \%)$ \\
Meningioma & $0(0 \%)$ & $1(100 \%)$ \\
Hippocampal atrophy/mesial temporal sclerosis & $0(0 \%)$ & $1(100 \%)$ \\
\hline
\end{tabular}

EEG: Electroencephalography, MRI: Magnetic resonance imaging 


\section{Discussion}

Syncope is a temporary loss of consciousness because of general cerebral hypoperfusion and is characterized by its short course, complete spontaneous recovery and postural loss of tone $(1,2,8)$. It represents the main symptom in $3 \%$ of all emergency room visits (8).

In vasovagal syncope, the reduced venous return to the heart triggers the reflex by decreasing the end-diastolic left ventricular volume. Powerful contractions in the face of low ventricular volume stimulates the cardiac mechanoreceptors. C-fibers emerging from these receptors are conveyed to the brainstem, leading to parasympathetic stimuli (9).

Generally, EEG examination in syncope patients is normal. In this study, $77 \%$ of EEG results of syncope patients are normal. Approximately $12 \%$ of all syncope cases, seizure like symptoms may occur due to global cranial hypoperfusion (6). If the acute phase is prolonged, syncope may be associated with the convulsive phenomena and may be confused with epilepsy (10). This is probably one of the reasons for the increase in EEG examinations performed in syncope patients.

Several convulsion-related findings such as myoclonic contractions, tonic spasms, or urinary incontinence may occur even in cardiovascular syncope; however, these are generally less severe and short-lived. In addition of these, these patients do not experience the confusion following an episode, and autonomic signs are more marked $(11,12)$. Thus, EEG is commonly requested particularly in patients with recurrent syncope or in those with convulsive phenomena after prolongation of the acute phase on the basis of the suspicion of epileptic seizures (10). There was no recurrent syncope history among the patients included in the study.

In this study, there was no statistically significant female/ male difference among the patients. Although previous studies suggested a female predominance among patients presenting with syncope (13), there was a higher number of male patients in our study; however, the difference was not significant $(\mathrm{p}=0.421)$. In addition, it has been reported that syncope risk increases equally in children of mothers with syncope and fathers increase risk only in boys (13). Also, there was no gender difference between those with EEG pathological $(\mathrm{p}=0.884)$ (Table 1$)$.

In epilepsy patients, EEG is important in supporting the diagnosis and monitoring of the patients with epilepsy diagnosis, but in epilepsy, the diagnosis is made clinically and EEG abnormalities do not suffice for a diagnosis. Interictal changes in EEG have been reported up to $30 \%$ in patients with syncope. These changes are generally diffuse or focal slowed-waves in the anterior regions of the head, and rarely spike or spike wave complexes (7). In our study, $60(23 \%)$ patients with abnormalities in interictal EEG were found. Of abnormalities in interictal EEG; $16.5 \%(n=43)$ of them were slow waves, and $6.5 \%(n=17)$ of them were found to be epileptiform discharges (spike/sharp waves).

During syncope, EEG is more often seen as "slow-flat-slow" or "slow" pattern. In particular, the slow-flat-slow pattern is related to deeper circulation, loss of longer consciousness, lower minimum blood pressure, RR-interval longer than the maximum and more associated with asystole, thus more severe hypoperfusion (5). In our study, in syncope patients, the EEG result was pathological in $23 \%(\mathrm{n}=60)$ of patients, and $16.5 \%(n=43)$ of them were slow waves, and $6.5 \%(n=17)$ of them were found to be epileptiform discharges (spike/ sharp waves).

Excluding epilepsy requires attention in syncope patients. In addition to epilepsy, EEG can also be helpful in assessing the consciousness of patients with asystole. If the duration of asystole is more than six seconds, syncope occurs frequently and is strongly associated with ictal syncope. Ictal syncope is more common in the left temporal seizures than in the right one (14). EEG slowed-waves were observed in patients with asystole, and syncope developed a few seconds after this slowed-waves. It was also found that the first EEG slowed-waves developed before the period of unconsciousness with syncope (15). In some patients, ictal syncope may be the earliest sign of epilepsy (16). This is also confusing.

In some cases, even pseudosyncope is encountered. The EEG in psychogenic pseudosyncope is typically normal or increased myogenic artifact with no suppression of background waveforms. But in the course of neural mediated syncope, it firstly shows a slowing of background rhythms and thereafter high-amplitude delta activity may progress to flattening appropriate with cerebral hypoperfusion (16).

In all these cases, EEG is used. The use of EEG increases the complexity of diagnosis, treatment, and cost, while neglecting the clinic.

Most of our patients were diagnosed as cardiogenic and vasovagal syncope after our examination. We found that environmental factors were more effective in patients with vasovagal syncope. Among these factors, stress, hunger, long-standing, and warm environment were the most. As 
a very remarkable result, only $6.1 \%(n=16)$ of our patients were diagnosed with seizure and treated for epilepsy.

\section{Study Limitations}

Our study has a limitation. Firstly, since this was a retrospective study, thus, the syncope was mostly reported by the patient, and no additional information could be obtained from patients' families. This situation precluded clinical assessment of the patients in point of epileptic seizures.

\section{Conclusion}

Since EEG recordings and/or video-EEG monitorization and even Holter as well as Tilt-table tests during syncope will be more informative clinically and so prospective studies are needed.

In the diagnosis of syncope patients, detailed anamnesis, medical history, and cardiovascular examination will provide more valuable information than EEG. In undetermined cases, an EEG should be performed. If the diagnosis is still obscure, the diagnosis of epilepsy should be delayed and the patient should be closely monitored.

\section{Ethics}

Ethics Committee Approval: The study was carried out according to the Helsinki Declaration and was approved by the Institutional Local Ethics Committee, University of Health Sciences Turkey, Dışkapı Yıldırım Beyazıt Training and Research Hospital (2019-71/01).

Informed Consent: For the study, written and verbal consent was obtained from the patients.

Peer-review: Externally peer-reviewed.

\section{Authorship Contributions}

Concept: M.P.A., Design: M.P.A., F.Y.C., Data Collection or Processing: M.P.A., F.Y.C., Analysis or Interpretation: M.P.A., Literature Search: M.P.A., F.Y.C., Writing: M.P.A.

Conflict of Interest: No conflict of interest was declared by the authors.

Financial Disclosure: The authors declared that this study has received no financial support.

\section{References}

1. Thijs RD, Benditt DG, Mathias CJ, Schondorf R, Sutton R, Wieling $\mathrm{W}$, et al. Unconscious confusion-a literature search for definitions of syncope and related disorders. Clin Auton Res 2005;15(1):35-39.

2. Altın T, Mürselov Ş, Beton O, Tulunay C, Akyürek Ö, Karaoğuz R, et al. Sinüs dügüm fonksiyon bozukluğu ve egzersiz sonrası oluşan vasovagal senkop. J Ankara Univ Fac Med 2003;56(2):121-126.

3. Moya A, Sutton R, Ammirati F, Blanc JJ, Brignole M, Dahm JB, et al. Task Force for the Diagnosis and Management of Syncope; European Society of Cardiology (ESC); European Heart Rhythm Association (EHRA); Heart Failure Association (HFA); Heart Rhythm Society (HRS), Guidelines for the diagnosis and management of syncope (version 2009). Eur Heart J 2009;30(21):2631-2671.

4. Wieling W, Thijs RD, van Dijk N, Wilde AA, Benditt DG, van Dijk JG. Symptoms and signs of syncope: a review of the link between physiology and clinical clues. Brain 2009;132(Pt 10):2630-2642.

5. van Dijk JG, Thijs RD, van Zwet E, Tannemaat MR, van Niekerk J, Benditt DG, et al. The semiology of tilt-induced reflex syncope in relation to electroencephalographic changes. Brain 2014;137(Pt 2):576-585.

6. McKeon A, Vaughan C, Delanty N. Seizure versus syncope. Lancet Neurol 2006;5(2):171-180.

7. Abubakr A, Wambacq I. The diagnostic value of EEGs in patients with syncope. Epilepsy Behav 2005;6(3):433-434.

8. Kapoor WN. Syncope. N Engl J Med 2000;343(25):1856-1862.

9. Van Lieshout JJ, Wieling W, Karemaker JM. Neural circulatory control in vasovagal syncope. Pacing Clin Electrophysiol 1997;20(3 Pt 2):753-763.

10. Lempert T, Bauer M, Schmidt D. Syncope: a videometric analysis of 56 episodes of transient cerebral hypoxia. Ann Neurol 1994;36(2):233-237.

11. Zaidi A, Clough P, Cooper P, Scheepers B, Fitzpatrick AP. Misdiagnosis of epilepsy: many seizure-like attacks have a cardiovascular cause. J Am Coll Cardiol 2000;36(1):181-184.

12. Britton JW. Syncope and seizures-differential diagnosis and evaluation. Clin Auton Res 2004;14(3):148-159.

13. Brignole M, Menozzi C, Bartoletti A, Giada F, Lagi A, Ungar A, et al. A new management of syncope: prospective systematic guidelinebased evaluation of patients referred urgently to general hospitals. Eur Heart J 2006;27(1):76-82.

14. Bestawros M, Darbar D, Arain A, Abou-Khalil B, Plummer D, Dupont WD, et al. Ictal asystole and ictal syncope: Insights into clinical management. Circ Arrhythm Electrophysiol 2015;8(1):159164 .

15. Heyer GL. Syncope is associated with electroencephalography changes. Clin Neurophysiol 2018;129(7):1496-1497.

16. Cheshire WP Jr. Syncope. Continuum (Minneap Minn) 2017;23(2, Selected Topics in Outpatient Neurology):335-358. 